НАУКОВИЙ ВІСНИК

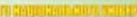

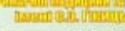

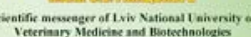

7

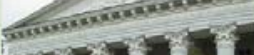

TIIII

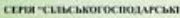
Tov 21 Nig 90

2019
Науковий вісник Дьвівського національного університету ветеринарної медицини та біотехнологій імені С.3. Гжицького. Серія: Сільськогосподарські науки

\author{
Scientific Messenger of Lviv National University
} of Veterinary Medicine and Biotechnologies.

Series: Agricultural sciences

ISSN 2519-2698 print

https://nvlvet.com.ua/index.php/agriculture

doi: $10.32718 /$ nvlvet-a9001

UDC 636.4.034/57.087

\title{
Effect of genetic and non-genetic factors on the reproduction traits in Ukrainian Meat sows
}

\author{
S.S. Kramarenko, S.I. Lugovoy, A.V. Lykhach, A.S. Kramarenko, V.Ya. Lykhach, A.A. Slobodianyk
}

Mykolayiv National Agrarian University, Mykolayiv, Ukraine

Article info

Received 21.01.2019

Received in revised form 20.02.2019

Mykolayiv National Agrarian University, Georgiya Gongadze Str., 9, Mykolayiv, 54020, Ukraine.

Tel.: +38-050-991-53-14

E-mail:kssnail0108@gmail.com
Accepted 21.02.2019

Kramarenko, S.S., Lugovoy, S.I., Lykhach, A.V., Kramarenko, A.S., Lykhach, V.Ya., \& Slobodianyk, A.A. (2019). Effect of genetic and non-genetic factors on the reproduction traits in Ukrainian Meat sows. Scientific Messenger of Lviv National University of Veterinary Medicine and Biotechnologies. Series: Agricultural sciences, 21(90), 3-8. doi: 10.32718/nvlvet-a9001

Purebred Ukrainian Meat (UM) breed pigs, which came from Limited Liability Company "Tavriyskie Svin'I" herd located in Skadovsky district (Kherson region, Ukraine), were studied. The reproduction traits investigated were total number of piglets born (TNB), number of piglets born alive (NBA), frequency of stillborn piglets (FSB), number of weaned piglets $(N W)$, total weaning weight of litter (TWWL) and average piglet weaning weight $(A P W W)$ for sows farrowing between 2006 and 2012. The analysis covered reproductive characteristics of 49 sows in the first nine parities $(n=457$ litters). The sows originated from different the UM dam lines. Two month farrowing periods (January/February, March/April, May/June, July/August, September/October, and November/December) were constructed and used for reproduction traits. Data were analyzed by use of general linear model (GLM) procedure with the statistical package MINITAB v. 15. The estimates of reproduction traits for UM sows were $10.73 \pm 0.43$ ind. for TNB, $9.36 \pm 0.39$ ind. for NBA, $10.5 \pm 2.2 \%$ for $F S B, 9.07 \pm 0.30$ ind. for $N W, 128.1 \pm 5.7 \mathrm{~kg}$ for TWWL and $14.39 \pm 0.49 \mathrm{~kg}$ for $A P W W$. Litter size had a nonlinear effect on probability of stillbirth; piglets from small and large litters were more susceptible to die at farrowing with a minimum probability (near 5.0\%) for intermediate litters of 8-10 piglets. Results here indicate that weak genetic variation exists in different the UM dam lines for the reproduction traits. Based on the obtained results it can be concluded that influence of parity on the observed traits of litter size was highly statistically significant $(P<0.05-0.001)$. The TNB, NBA and NW decreased in the first-second parities and thereafter increased with the number of parities, reaching a maximum in parities 5 and 6. FSB was lowest in parities 2, 3 and 5. Farrowing month significantly influenced some reproduction traits also. Sows farrowing in May/June had the highest NW, TWWL and APWW.

Key words: parity, farrowing year and month, dam line, reproduction traits, Ukrainian Meat breed, sows.

\section{Вплив генетичних та негенетичних факторів на відтворювальні ознаки свиноматок української м'ясної породи}

\author{
С.С. Крамаренко, С.І. Луговий, А.В. Лихач, О.С. Крамаренко, В.Я. Лихач, А.А. Слободяник
}

Миколаївський національний аграрний університет, м. Миколаӥв, Україна 
лом для досліджених тварин було отримано такі середні популяційні очінки для ознак відтворення: загальна кількість поросят

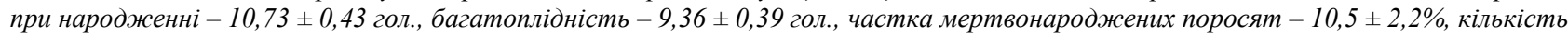
поросят при відлученні - 9,07 \pm 0,30 гол., загальна маса гнізда при відлученні - 128,1 \pm 5,7 кг та середня маса одного поросяти при відлученні - 14,39 \pm 0,49 кг. Встановлено: наявність криволінійної залежності частки мертвонароджених поросят від загальної кількості поросят при народженні; поросята із найменш та найбільш чисельних гнізд мали вищу імовірність загинути при опороci; найменшу частку мертвонароджених поросят (близько 5,0\%) було зафіксовано для гнізд, шуо складалися з 8-10 поросят. Встановлено слабку генетичну мінливість відтворювальних ознак у свиноматок УМ породи із різних родин. Отримані результати свідчать, щуо номер опоросу суттєво впливає на розмір гнізда (P<0,05-0,001). Оцінки TNB, NBA та NW у свиноматок 1-2-го опоросів були нижчими, але суттєво збільиувалися зі зростанням номера опоросу, досягаючи максимуму під час 5-6-го опоросів. Частка мертвонароджених поросят була найнижчою під час 2-го, 3-го та 5-го опоросів. Місяџь опоросу також впливав на відтворювальні ознаки. Свиноматки, які опоросилися протягом травня/червня, характеризувалися найвищими показниками кількості поросят, загальної маси гнізда та середньої маси одного поросяти при відлученні.

Ключові слова: номер опоросу, рік та місяџь опоросу, родина, відтворювальні ознаки, украӥнська м'ясна порода, свиноматки.

\section{Вступ}

Продуктивність свиноматок є ключовим фактором, що впливає на економічну ефективність галузі свинарства і $є$ основною проблемою комерційних виробників та селекціонерів, що може бути вирішена через збільшення кількості поросят, отриманих від однієї свиноматки протягом року. При розробці сучасних програм селекції суттєва увага насамперед повинна приділятися поліпшенню відтворювальних ознак свиноматок спеціалізованих ліній та родин (Hanenberg et al., 2001).

При аналізі факторів, що значною мірою зумовлюють масу гнізда поросят йоркширської породи при народженні та відлученні, було встановлено, що більшість економічно важливих ознак відтворення свиноматок тісно пов'язані між собою (Fahmy \& Bernard, 1972). Таким чином, будь-яка схема селекційної роботи, спрямованої на поліпшення однієї чи декількох ознак, також буде ефективною для поліпшення інших, корельованих 3 ними. Наприклад, цими ж дослідниками було показано, що селекція на масу гнізда при відлученні, що часто використовується як найкращий інтегральний показник відтворення свиней, пов'язана зі збільшенням розміру гнізда, збереженості та приростів поросят до відлучення. Наявність високих та позитивних не лише фенотипових, а й генетичних кореляцій між кількістю поросят та масою гнізда як при народженні, так і при відлученні було також доведено в роботі L. Young зі співавторами (Young et al., 1978).

Встановлено, що у свиней до $8 \%$ новонароджених поросят у гнізді - мертвонароджені, найчастіше внаслідок перинатальної асфіксії під час їхнього перебування у матці чи родових шляхах свиноматки (Randall, 1978; Zaleski \& Hacker, 1993). При цьому ця частка має тенденцію до збільшення, оскільки тісно пов'язана з наслідками селекційної роботи, спрямованої на підвищення багатоплідності свиноматок.

Крім генетичних факторів, таких як порода або внутрішньопородні одиниці (лінії кнура чи свиноматки), доведено суттєвий вплив на відтворювальні ознаки свиней негенетичних (в т. ч., середовищних) факторів, насамперед номера опоросу (Tantasuparuk et al., 2000; Canario et al., 2006; Schwarz et al., 2009), а також року та/або сезону опоросу (Leigh, 1977; Love et al., 1993; Tantasuparuk et al., 2000; Imboonta et al., 2007; Schwarz et al., 2009).

Також було виявлено сумісний вплив “порода $\times$ сезон опоросу" на розмір гнізда при народженні у свиноматок порід велика біла та дюрок (але лише для свиноматок 1-5-го опоросів) та на частку мертвонароджених поросят. Так, зі зростанням кількості новонароджених поросят у гнізді збільшувалася частка мертвонароджених. При цьому великоплідність мала тенденцію до зменшення на 0,01 кг для кожного додаткового поросяти в гнізді (Leigh, 1977).

3 іншого боку, відмічено збільшення рівня багатоплідності свиноматок у середньому на 0,07-0,10 гол. в розрахунку на кожне додаткове порося у гніздах, в яких вони були народжені (Tummaruk et al., 2001).

Таким чином, головною метою нашої роботи був аналіз впливу генетичних та негенетичних факторів на відтворювальні ознаки свиноматок української м'ясної породи 3 особливим розглядом характеру мінливості частки мертвонароджених поросят.

\section{Матеріал і методи досліджень}

В аналізі було використано дані щодо 457 опоросів свиноматок української м'ясної породи (УМП), що утримувалися в умовах ТОВ “Таврійські свині” Скадовського району Херсонської області. Тварини були спаровані з кнурами тієї ж породи.

Для кожної свиноматки було оцінено такі ознаки відтворення: загальна кількість поросят при народженні (TNB - total no. piglets born), багатоплідність (NBA - no. piglets born alive), частка мертвонароджених поросят (FSB - freq. of stillborn piglets), кількість поросят при відлученні (NW - no. weaned piglets), загальна маса гнізда при відлученні (TWWL - total weaning weight of litter) та середня маса одного поросяти при відлученні (APWW - average piglet weaning weight).

Для аналізу впливу генетичних та негенетичних факторів на ознаки відтворення свиноматок УМП нами було використано алгоритм Загальної Лінійної Моделі (GLM). Використана модель у загальному вигляді мала такий вигляд:

$$
Y_{i j k l}=\mu+D L_{i}+P_{j}+Y_{k}+S_{l}+e_{i j k l}
$$

де $Y_{i j k l}$ - ознаки відтворення; $\mu$ - середнє популяційне; $D L_{i}$ - родина свиноматки (вісім градацій: Царапинка, Цензура, Ценная, Цикада, Цинга, Цитадель, Цитата, Цифра); $P_{j}-$ номер опоросу (дев'ять градацій: від 1-го до 9-го); $Y_{k}$ - рік опоросу (сім градацій: 20062012 pp.); $S_{l}-$ сезон опоросу (шість градацій: січень- 
лютий, березень-квітень, травень-червень, липеньсерпень, вересень-жовтень, листопад-грудень); $e_{i j k l}-$ помилки.

Для окремих градацій факторів, що були включені в модель (1), розраховано оцінки коефіцієнтів за допомогою LSM-процедури (Least squares means $\pm S E$ ), а також визначено рівень вірогідності їх відхилення від нуля (Р-оцінки). Всі розрахунки проведено за допомогою модуля “GLM” пакету прикладних програм MINITAB v. 15 (Ryan et al., 2012).

\section{Результати та їх обговорення}

Загалом для досліджених тварин отримано такі середні популяційні оцінки для ознак відтворення свиноматок УМП: загальна кількість поросят при народженні - 10,73 \pm 0,43 гол., багатоплідність - 9,36 \pm 0,39 гол., частка мертвонароджених поросят $-10,5 \pm$ 2,2\%, кількість поросят при відлученні - 9,07 0,30 гол., загальна маса гнізда при відлученні $128,1 \pm 5,7$ кг та середня маса одного поросяти при відлученні - 14,39 \pm 0,49 кг.

Встановлено наявність криволінійної залежності частки мертвонароджених поросят від загальної кількості поросят при народженні у досліджених свиноматок УМП (рис. 1).

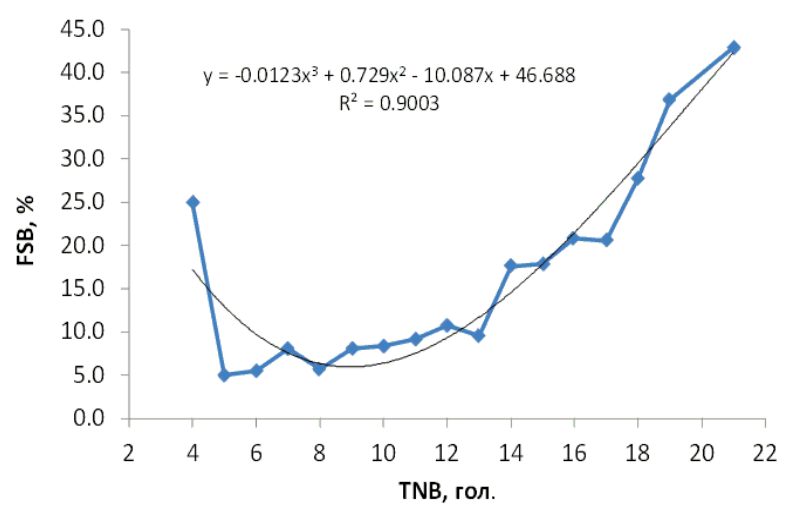

Рис. 1. Залежність частки мертвонароджених поросят (FSB) від загальної кількості поросят при народженні (TNB) свиноматок УМП. (Наведено апроксимуючу криву за моделлю поліному 3-го ступеня та коефіцієнт ії детермінації, $\mathrm{R}^{2}$ )
При цьому поросята із найменш та найбільш чисельних гнізд мали вищу ймовірність загинути при опоросі. Найменшу частку мертвонароджених поросят (близько 5,0\%) зафіксовано для гнізд, що мали 8-10 поросят. Аналогічну закономірність раніше було встановлено для свиноматок порід велика біла та помісей велика біла $\times$ дюрок. Проте у свиноматок породи мейшан частка мертвонароджених поросят не залежала від розміру гнізда (Canario et al., 2006). Biрогідний позитивний зв'язок між розміром гнізда та кількістю мертвонароджених поросят було відзначено також у роботі J. Leenhouwers зі спів. (Leenhouwers et al., 1999) для свиноматок різних порід (п’єтрен, велика біла та ін.). Водночас тривалість поросності та великоплідність, навпаки, були негативно пов'язані 3 кількістю мертвонароджених поросят. Оптимальний розмір гнізда (такий, при якому частка мертвонароджених поросят найнижча), за даними L. Canario зі спів. (Canario et al., 2006), становив 12 гол. Проте в роботі H. Zaleski та R. Hacker (Zaleski \& Hacker, 1993) ця оцінка ближча до отриманої в нашому дослідженні -9 гол.

Вірогідний вплив родинної належності на ознаки відтворення відмічено лише для свиноматок трьох родин - Царапинки, Цикади та Цитаделі (табл. 1).

Так, у свиноматок родини Царапинки встановлено вірогідно вищі значення загальної маси гнізда при відлученні (на 10,3 кг; Р < 0,05) та середньої маси одного поросяти при відлученні (на 1,28 кг; Р <0,05).

Свиноматки родини Цикади характеризувалися нижчою часткою мертвонароджених поросят (на 2,9\%; Р < 0,05), але при цьому середня маса одного поросяти при відлученні у цих свиноматок була вірогідно нижчою (на 0,91 кг; Р $<0,01$ ). У свиноматок родини Цитаделі встановлено вірогідно низьке значення багатоплідності (на 0,48 гол.; $\mathrm{P}<0,05$ ), що пов'язано із вищої часткою мертвонароджених поросят (на 2,7\%; Р <0,05).

Загалом LSM-оцінки, отримані для трьох ознак багатоплідності (TNB, NBA та NW), не мають збігів у свиноматок різних родин УМП (критерій Фрідмана: $\left.\chi^{2}=0,86 ; d f=2 ; P=0,70\right)$, що свідчить про значний вплив негенетичних факторів на ці ознаки.

Таблиця 1

LSM-оцінки $( \pm S E)$ впливу родини свиноматок УМП на їх ознаки відтворення

\begin{tabular}{|c|c|c|c|c|c|c|}
\hline $\begin{array}{c}\text { Родина } \\
\text { (Dam line) }\end{array}$ & $\begin{array}{l}\mathrm{TNB}^{2} \\
\text { (гол.) }\end{array}$ & $\begin{array}{l}\text { NBA } \\
\text { (гол.) }\end{array}$ & $\begin{array}{l}\text { FSB } \\
(\%)\end{array}$ & $\begin{array}{c}\text { NW } \\
\text { (гол.) }\end{array}$ & TWWL (кг) & $\begin{array}{c}\text { APWW } \\
\text { (кг) }\end{array}$ \\
\hline Црп & $-0,12 \pm 0,51$ & $0,17 \pm 0,46$ & $-2,5 \pm 2,6$ & $-0,03 \pm 0,33$ & $10,3 \pm 5,2^{*}$ & $1,28 \pm 0,53^{*}$ \\
\hline Цнз & $0,04 \pm 0,30$ & $0,20 \pm 0,27$ & $-1,4 \pm 1,5$ & $0,30 \pm 0,20$ & $-0,4 \pm 3,8$ & $-0,51 \pm 0,33$ \\
\hline Цен & $-0,11 \pm 0,53$ & $0,01 \pm 0,47$ & $-1,1 \pm 2,7$ & $-0,25 \pm 0,36$ & $-1,5 \pm 6,8$ & $0,12 \pm 0,58$ \\
\hline Цкд & $-0,18 \pm 0,30$ & $0,19 \pm 0,27$ & $-2,9 \pm 1,4^{*}$ & $0,38 \pm 0,22$ & $-3,4 \pm 4,1$ & $-0,91 \pm 0,35 * *$ \\
\hline Цнг & $-0,09 \pm 0,34$ & $-0,06 \pm 0,30$ & $-0,2 \pm 1,7$ & $-0,21 \pm 0,23$ & $-1,3 \pm 4,4$ & $0,19 \pm 0,38$ \\
\hline Цтд & $-0,18 \pm 0,31$ & $-0,48 \pm 0,23 *$ & $2,7 \pm 1,4^{*}$ & $-0,04 \pm 0,23$ & $-3,9 \pm 4,3$ & $-0,42 \pm 0,37$ \\
\hline Цтт & $-0,04 \pm 0,34$ & $-0,22 \pm 0,30$ & $2,2 \pm 1,7$ & $-0,11 \pm 0,24$ & $1,6 \pm 4,5$ & $0,49 \pm 0,39$ \\
\hline Цфр & 0 & 0 & 0 & 0 & 0 & 0 \\
\hline
\end{tabular}

Примітки. $^{1}$ Црп - Царапинка; Цнз - Цензура; Цен - Ценная; Цкд - Цикада; Цнг - Цинга; Цтд - Цитадель; Цтт - Цитата; Цфр - Цифра.

2 Тут і далі: TNB - загальна кількість поросят при народженні; NBA - багатоплідність; FSB - частка мертвонароджених поросят; NW - кількість поросят при відлученні; TWWL - загальна маса гнізда при відлученні; APWW середня маса одного поросяти при відлученні. * $-\mathrm{P}<0,05 ; * *-\mathrm{P}<0,01$; *** $-\mathrm{P}<0,001$. 
Серед таких факторів одним із важливіших $є$ номер опоросу свиноматок. Нами також встановлено вірогідний вплив на ознаки відтворення свиноматок номера їхнього опоросу (табл. 2).

За показником загальної кількості поросят при народженні свиноматки 1-2-го опоросів вірогідно поступалися на 0,84-1,10 гол. (в обох випадках: $\mathrm{P}<0,05)$. Водночас свиноматки 5-6-го опоросів, навпаки, вірогідно переважали тварин інших вікових груп на 0,670,78 гол. (в обох випадках: $\mathrm{P}<0,05$ ). Свиноматки протягом 5-го опоросу характеризувалися найвищим рівнем багатоплідності (на 1,07 гол.; Р < 0,001). Вірогідне переважання за рівнем багатоплідності відмічено також серед свиноматок за третім (на 0,81 гол.; $\mathrm{P}<0,01$ ) та шостим (на 0,73 гол.; $\mathrm{P}<0,05$ ) опоросами.

Також, як і для свиноматок УМП, раніше було відзначено суттєве зростання загальної кількості поросят при народженні та багатоплідності до 5-го опоросу та ïx зниження у тварин старшого віку польської великої білої породи (Schwarz et al., 2009).

\section{Таблиця 2}

LSM-оцінки $( \pm S E)$ впливу номера опоросу на ознаки відтворення свиноматок УМП

\begin{tabular}{ccccccc}
\hline $\begin{array}{c}\text { Oпорос } \\
\text { (Parity) }\end{array}$ & $\begin{array}{c}\text { TNB } \\
\text { (гол.) }\end{array}$ & $\begin{array}{c}\text { NBA } \\
\text { (гол. })\end{array}$ & $\begin{array}{c}\text { FSB } \\
(\%)\end{array}$ & $\begin{array}{c}\text { NW } \\
\text { (гол.) }\end{array}$ & $\begin{array}{c}\text { TWWL (кг) } \\
\text { APWW } \\
\text { (кг) }\end{array}$ \\
\hline 1 & $-1,10 \pm 0,45^{*}$ & $-0,49 \pm 0,40$ & $-3,8 \pm 2,2$ & $-0,89 \pm 0,33^{* *}$ & $-8,8 \pm 6,2$ & $0,15 \pm 0,53$ \\
2 & $-0,84 \pm 0,37^{*}$ & $0,02 \pm 0,33$ & $-6,2 \pm 1,9^{* * *}$ & $-0,77 \pm 0,28^{* *}$ & $-5,7 \pm 5,3$ & $0,60 \pm 0,45$ \\
3 & $0,33 \pm 0,34$ & $0,81 \pm 0,31^{* *}$ & $-4,6 \pm 1,7 * *$ & $0,10 \pm 0,27$ & $1,0 \pm 5,0$ & $-0,10 \pm 0,42$ \\
4 & $0,18 \pm 0,35$ & $0,43 \pm 0,32$ & $-2,5 \pm 1,8$ & $-0,10 \pm 0,26$ & $5,9 \pm 4,9$ & $0,80 \pm 0,40^{*}$ \\
5 & $0,67 \pm 0,33^{*}$ & $1,07 \pm 0,32^{* * *}$ & $-3,9 \pm 1,8^{*}$ & $0,40 \pm 0,27$ & $5,4 \pm 5,1$ & $-0,06 \pm 0,44$ \\
6 & $0,78 \pm 0,38^{*}$ & $0,73 \pm 0,34^{*}$ & $-1,1 \pm 1,9$ & $-0,17 \pm 0,28$ & $4,2 \pm 5,3$ & $0,62 \pm 0,45$ \\
7 & $0,49 \pm 0,61$ & $-0,15 \pm 0,55$ & $4,7 \pm 3,1$ & $-0,30 \pm 0,43$ & $-10,9 \pm 8,1$ & $-0,65 \pm 0,69$ \\
8 & $0,06 \pm 0,84$ & $-1,02 \pm 0,76$ & $6,5 \pm 4,2$ & $0,24 \pm 0,72$ & $6,1 \pm 13,5$ & $0,03 \pm 1,16$ \\
9 & 0 & 0 & 0 & 0 & 0 & 0 \\
\hline
\end{tabular}

Відзначено чітко виражену тенденцію до підвищення частки мертвонароджених поросят із віком свиноматок. Найнижчі значення цієї ознаки було нами відзначено у свиноматок УМП протягом 2-го (на $6,2 \% ;$ Р < 0,001), 3-го (на 4,6\%; Р <0,01) та 5-го (на $3,9 \%$; $\mathrm{P}<0,05)$ опоросів. Тенденцію до підвищення частки мертвонароджених поросят із зростанням номера опоросу раніше вже було відзначено для свиноматок порід велика біла та помісей велика біла $\times$ дюрок (Canario et al., 2006). Дана закономірність найчастіше пояснюється або суттєвим осалюванням свиноматок, або зниженням м'язового тонусу матки із ві- ком, що робить менш ефективними процеси опоросу (Leenhouwers et al., 1999; Borges et al., 2005).

Кількість поросят при відлученні, як і у випадку загальної кількості поросят при народженні, була вірогідно нижчою у свиноматок 1-2-го опоросів (на 0,77-0,89 гол.; в обох випадках: $\mathrm{P}<0,01)$. А ось на масу при відлученні (як гнізда, так і одного поросяти) номер опоросу практично не впливав. Відзначено лише вірогідне підвищення середньої маси одного поросяти при відлученні (на 0,80 кг; Р < 0,05) у свиноматок УМП протягом 4-го опоросу.

Рік опоросу незначно впливав на прояв ознак відтворення свиноматок УМП (табл. 3).

Таблиця 3

LSM-оцінки $( \pm S E)$ впливу року опоросу на ознаки відтворення свиноматок УМП

\begin{tabular}{ccccccc}
\hline $\begin{array}{c}\text { Piк } \\
\text { Year of } \\
\text { farrowing) }\end{array}$ & $\begin{array}{c}\text { TNB } \\
\text { (гол.) }\end{array}$ & $\begin{array}{c}\text { NBA } \\
\text { (гол.) }\end{array}$ & $\begin{array}{c}\text { FSB } \\
(\%)\end{array}$ & $\begin{array}{c}\text { NW } \\
\text { (гол.) }\end{array}$ & $\begin{array}{c}\text { TWWL (кг) } \\
\text { APWW } \\
\text { (кг) }\end{array}$ \\
\hline 2006 & $-1,72 \pm 1,52$ & $-0,72 \pm 1,36$ & $-11,8 \pm 7,6$ & $-1,02 \pm 0,97$ & $-4,7 \pm 18,3$ & $1,50 \pm 1,57$ \\
2007 & $0,06 \pm 0,98$ & $0,37 \pm 0,89$ & $-4,8 \pm 5,0$ & $-1,07 \pm 0,64$ & $-14,9 \pm 11,9$ & $0,39 \pm 1,02$ \\
2008 & $0,72 \pm 0,51$ & $0,55 \pm 0,46$ & $1,9 \pm 2,6$ & $0,76 \pm 0,34 *$ & $-5,7 \pm 6,3$ & $-1,72 \pm 0,54 * *$ \\
2009 & $0,15 \pm 0,52$ & $0,06 \pm 0,47$ & $1,8 \pm 2,6$ & $0,21 \pm 0,35$ & $3,4 \pm 6,6$ & $-0,14 \pm 0,57$ \\
2010 & $0,25 \pm 0,56$ & $-0,25 \pm 0,51$ & $4,4 \pm 2,8$ & $0,18 \pm 0,37$ & $-5,8 \pm 7,0$ & $-1,05 \pm 0,60$ \\
2011 & $0,38 \pm 0,62$ & $0,04 \pm 0,56$ & $3,6 \pm 3,1$ & $-0,11 \pm 0,41$ & $-2,7 \pm 7,8$ & $-0,33 \pm 0,67$ \\
2012 & 0 & 0 & 0 & 0 & 0 & 0 \\
\hline
\end{tabular}

Зафіксовано, що свиноматки, які мали опороси у 2008 році, характеризувалися вірогідно вищою кількістю поросят при відлученні (на 0,76 гол.; Р < 0,05), але ці поросята в середньому мали більш низьку живу масу (на 1,72 кг; Р <0,05).

Більш суттєвий вплив на ознаки відтворення свиноматок УМП відзначено для сезону опоросу (табл. 4). Але цей вплив проявлявся лише на ознаки, що характеризують поросят при відлученні. Так, свиноматки, які мали зимові опороси (протягом січнялютого) вірогідно поступалися за кількістю поросят при відлученні (на 0,40 гол.; Р < 0,05), загальною масою гнізда при відлученні (на 14,6 кг; Р < 0,001) та середньою масою одного поросяти при відлученні (на $0,83$ кг; $\mathrm{P}<0,05)$. 
Таблищя 4

LSM-оцінки $( \pm S E)$ впливу сезону опоросу на ознаки відтворення свиноматок УМП

\begin{tabular}{|c|c|c|c|c|c|c|}
\hline $\begin{array}{c}\mathrm{Cезон}^{1} \\
\text { (Season of } \\
\text { farrowing) }\end{array}$ & $\begin{array}{l}\mathrm{TNB} \\
\text { (гол.) }\end{array}$ & $\begin{array}{l}\text { NBA } \\
\text { (гол.) }\end{array}$ & $\begin{array}{l}\text { FSB } \\
(\%)\end{array}$ & $\begin{array}{l}\mathrm{NW} \\
\text { (гол.) }\end{array}$ & TWWL (кг) & $\begin{array}{c}\text { APWW } \\
\text { (кг) }\end{array}$ \\
\hline $\mathrm{J}-\mathrm{F}$ & $-0,29 \pm 0,32$ & $-0,38 \pm 0,28$ & $0,1 \pm 1,6$ & $-0,40 \pm 0,20 *$ & $-14,6 \pm 4,0^{* * *}$ & $-0,83 \pm 0,34^{*}$ \\
\hline M-A & $0,16 \pm 0,28$ & $0,22 \pm 0,26$ & $-0,2 \pm 1,4$ & $-0,25 \pm 0,20$ & $-2,1 \pm 3,7$ & $-0,04 \pm 0,32$ \\
\hline M-J & $0,21 \pm 0,28$ & $0,44 \pm 0,25$ & $-2,0 \pm 1,4$ & $0,45 \pm 0,19 *$ & $15,0 \pm 3,6^{* * *}$ & $0,93 \pm 0,31 * *$ \\
\hline $\mathrm{J}-\mathrm{A}$ & $-0,08 \pm 0,28$ & $-0,12 \pm 0,25$ & $-0,2 \pm 1,4$ & $0,18 \pm 0,21$ & $6,6 \pm 3,9$ & $0,39 \pm 0,33$ \\
\hline $\mathrm{S}-\mathrm{O}$ & $-0,15 \pm 0,31$ & $-0,30 \pm 0,28$ & $1,6 \pm 1,5$ & $0,08 \pm 0,22$ & $-0,4 \pm 4,2$ & $-0,14 \pm 0,36$ \\
\hline N-D & 0 & 0 & 0 & 0 & 0 & 0 \\
\hline
\end{tabular}

Примітки: ${ }^{1} \mathrm{~J}-\mathrm{F}$ - січень-лютий; М-А - березень-квітень; М-J - травень-червень; Ј-А - липень-серпень; S-O - вересеньжовтень; N-D - листопад-грудень.

3 іншого боку, свиноматки, які мали опороси протягом травня-червня, навпаки, вірогідно переважали за кількістю поросят при відлученні (на 0,45 гол.; $\mathrm{P}<0,05)$, загальною масою гнізда при відлученні (на $15,0$ кг; Р $<0,001)$ та середньою масою одного поросяти при відлученні (на 0,93 кг; Р <0,05).

Сезонні зміни в репродуктивній діяльності свиноматок відзначено для різних кліматичних умов. Основними факторами навколишнього середовища, що впливають на їхні репродуктивні ознаки, $є$ фотоперіод, температура та вологість. Але температура і вологість вважаються більш суттєвими в тропічних умовах, тимчасом як фотоперіод є найважливішим фактором у помірному кліматі (Love et al., 1993; Prunier et al., 1997; Tantasuparuk et al., 2000).

Більшу кількість поросят при відлученні відзначено у свиноматок польської великої білої породи, які були запліднені у зимові місяці (Schwarz et al., 2009). При цьому різні породи можуть по-різному реагувати на фактори зовнішнього середовища. Так, для породи йоркшир свиноматки, які опоросилися 3 жовтня по березень мали вірогідно більші оцінки TNB, NBA та NW. Водночас їхні ровесниці породи ландрас, навпаки, мали нижчі оцінки, особливо кількості поросят при відлученні (Southwood \& Kennedy, 1991). Аналогічні результати було відзначено нами і для свиноматок УМП.

3 іншого боку, для свиней породи ландрас, що розводилися в Таїланді, кількість мертвонароджених поросят була найменшою серед свиноматок, які опоросилися протягом вересня-жовтня (не залежно від номеру їх опоросу) та найвищою серед свиноматокпершоопоросок, які опоросилися у травні-червні (Imboonta et al., 2007).

\section{Висновки}

1. Встановлено наявність криволінійної залежності частки мертвонароджених поросят від загальної кількості поросят при народженні; поросята із найменш та найбільш чисельних гнізд мали вищу ймовірність загинути при опоросі; найменшу частку мертвонароджених поросят (близько 5,0\%) було зафіксовано для гнізд, що мали 8-10 поросят.

2. Встановлено слабку генетичну мінливість відтворювальних ознак у свиноматок УМ породи із різних родин.
3. Номер опоросу суттєво впливає на розмір гнізда (P $<0,05-0,001)$. Оцінки загальної кількості поросят при народженні, багатоплідності та кількості поросят при відлученні знижувалися у свиноматок 1-2-го опоросів, але суттєво збільшувалися зі зростанням номера опоросу, досягаючи максимуму під час 5-6-го опоросу. Частка мертвонароджених поросят була найнижчою під час 2-го, 3-го та 5-го опоросів.

4. Місяць опоросу також впливав на відтворювальні ознаки. Свиноматки, які опоросилися протягом травня/червня характеризувалися найвищими показниками кількості поросят при відлученні, загальної маси гнізда та середньої маси одного поросяти при відлученні.

Подяки. Робота виконана в рамках фінансування за держбюджетною тематикою Міністерства освіти і науки України (номер державної реєстрації 0117U000485).

\section{References}

Borges, V.F., Bernardi, M.L., Bortolozzo, F.P., \& Wentz, I. (2005). Risk factors for stillbirth and foetal mummification in four Brazilian swine herds. Preventive Veterinary Medicine, 70(3-4), 165-176. doi: 10.1016/j.prevetmed.2005.03.003.

Canario, L., Cantoni, E., Le Bihan, E., Caritez, J.C., Billon, Y., Bidanel, J.P., \& Foulley, J.L. (2006). Between-breed variability of stillbirth and its relationship with sow and piglet characteristics. Journal of Animal Science, 84(12), 3185-3196. doi: 10.2527/jas.2005775.

Fahmy, M.H., \& Bernard, C.S. (1972). Interrelations between some reproductive traits in swine. Canadian Journal of Animal Science, 52(1), 39-45. doi: 10.4141/cjas72-004.

Hanenberg, E.H.A.T., Knol, E.F., \& Merks, J.W.M. (2001). Estimates of genetic parameters for reproduction traits at different parities in Dutch Landrace pigs. Livestock Production Science, 69(2), 179-186. doi: 10.1016/S0301-6226(00)00258-X.

Imboonta, N., Rydhmer, L., \& Tumwasorn, S. (2007). Genetic parameters for reproduction and production traits of Landrace sows in Thailand. Journal of animal science, 85(1), 53-59. doi:_10.2527/jas.2005-708.

Leenhouwers, J.I., van der Lende, T., \& Knol, E.F. (1999). Analysis of stillbirth in different lines of pig. 
Livestock Production Science, 57(3), 243-253. doi: 10.1016/S0301-6226(98)00171-7.

Leigh, A.O. (1977). Litter performance characteristics of pigs in tropical south-western Nigeria 1. Breed differences and effects of some non-genetic sources of variation. Animal Science, 24(3), 323-331. doi: 10.1017/S0003356100011831.

Love, R.J., Evans, G., \& Klupiec, C. (1993). Seasonal effects on fertility in gilts and sows. Journal of Reproduction and Fertility. Supplement, 48, 191-206. https://www.ncbi.nlm.nih.gov/pubmed/8145204.

Prunier, A., de Braganca, M.M., \& Le Dividich, J. (1997). Influence of high ambient temperature on performance of reproductive sows. Livestock Production Science, 52(2), 123-133. doi: 10.1016/S0301-6226(97)00137-1.

Randall, G.C.B. (1978). Perinatal mortality: Some problems of adaptation at birth. Advances in Veterinary Science and Comparative Medicine, 22, 53-81.

Ryan, B.F., Joiner, B.L., \& Cryer, J.D. (2012). MINITAB Handbook: Update for release 16. Pacific Grove, CA, USA: Brooks/Cole Publishing Co., 560 p.

Schwarz, T., Nowicki, J., \& Tuz, R. (2009). Reproductive performance of Polish Large White sows in intensive production: effect of parity and season. Annals of Animal Science, 9(3), 268-277.
Southwood, O.I., \& Kennedy, B.W. (1991). Genetic and environmental trends for litter size in swine. Journal of Animal Science, 69(8), 3177-3182. doi: $10.2527 / 1991.6983177 x$.

Tantasuparuk, W., Lundeheim, N., Dalin, A.M., Kunavongkrit, A., \& Einarsson, S. (2000). Reproductive performance of purebred Landrace and Yorkshire sows in Thailand with special reference to seasonal influence and parity number. Theriogenology, 54(3), 481-496. doi: 10.1016/S0093-691X(00)00364-2.

Tummaruk, P., Lundeheim, N., Einarsson, S., \& Dalin, A.M. (2001). Effect of birth litter size, birth parity number, growth rate, backfat thickness and age at first mating of gilts on their reproductive performance as sows. Animal Reproduction Science, 66(3-4), 225237. doi: 10.1016/S0378-4320(01)00095-1.

Zaleski, H.M., \& Hacker, R.R. (1993). Effect of oxygen and neostigmine on stillbirth and pig viability. Journal of Animal Science. 71(2), 298-305. doi: 10.2527/1993.712298x.

Young, L.D., Pumfrey, R.A., Cunningham, P.J., \& Zimmerman, D.R. (1978). Heritabilities and genetic and phenotypic correlations for prebreeding traits, reproductive traits and principal components. Journal of Animal Science, 46(4), 937-949. doi: $10.2527 /$ jas $1978.464937 x$. 